\title{
Environmentally sustainable investment: Dynamics between global thematic indices
}

\section{Inversión ambientalmente sostenible: Dinámica entre índices temáticos mundiales}

\author{
VÍtor Gabriel ${ }^{1}$ \\ Polytechnic Institute of Guarda (Portugal)
}

Recibido el 21 de mayo de 2015, aceptado el 13 de octubre de 2016

Publicado online el 20 de febrero de 2018

$\mathrm{N}^{\mathrm{o}}$ de clasificación JEL: Q01, C58

DOI: $10.5295 / \mathrm{cdg} .150545 \mathrm{vg}$

\begin{abstract}
:
This study analyses the long-term and short-term dynamics established between environmentally sustainable investment segments, applying a diverse methodological proposal based on the Johansen cointegration approach, Granger causality concept, and impulse response functions and considering a multivariate asymmetric GARCH model. Five environmental investment segments were selected, in particular concerning alternative energy, clean technology, green building, sustainable water, and pollution prevention.

The results show that the investment segments do not follow similar paths in the long term. In the short term, sustainable water is particularly autonomous and contributes to explaining the movements in the remaining segments. Evidence of own and cross-contagion effects was found as well as asymmetric volatility effects. This poses great challenges for investors in diversifying investment.
\end{abstract}

\section{Keywords:}

Sustainable investment, thematic indices, cointegration, vector autoregression, impulse response, multivariate asymmetric GARCH.

\section{Resumen:}

Este estudio analiza las relaciones dinámicas de corto y largo plazo entre segmentos de inversión ambientalmente sostenible, mediante la aplicación de una propuesta metodológica basada en la prueba de cointegración de Johansen, en el concepto de causalidad, en funciones de impulso-respuesta generalizadas, y en un modelo GARCH multivariante asimétrico. Se han seleccionado índices de cinco segmentos de inversión sostenible, relacionados con la energía alternativa, la tecnología limpia, la construcción ecológica, el agua sostenible y la prevención de la polución.

Los resultados muestran que los índices no han seguido caminos análogos en el largo plazo. En lugar de ello, los índices han seguido caminos autónomos. En el corto plazo, el índice agua sostenible fue particularmente autónomo, y contribuyó para ayudar a explicar los movimientos en los restantes índices. Han sido identificados efectos de contagio, pero también efecto asimétrico sobre la volatilidad de los índices temáticos. Esta situación plantea grandes retos a los inversores de cara a una estrategia de diversificación de la inversión.

1 UDI - Research Unit for Inland Development. Department of Management and Economics. Superior School of Technology and Management, Avenida Dr. Francisco Sá Carneiro, n. ${ }^{\circ}$ 50, 6300-559 Guarda (Portugal). vigab@ipg.pt 


\section{Palabras clave:}

Inversión sostenible, índices temáticos, cointegración, vector autorregresivo, funciones de impulso-respuesta, GARCH multivariante asimétrico. 


\section{INTRODUCTION}

In the past business management models have fundamentally followed the financial point of view. However, in recent decades there has been a change in management models to accommodate the different perspectives of stakeholders. The idea that the only mission of an enterprise is to maximize shareholder value, inspired by Friedman's (1970) proposal, has been questioned by several researchers (Freeman 2008; Wood 2008).

The combined effect of the financial crisis, extensive information about the consequences of global warming, concerns about water shortages, issues relating to human rights and poverty, governance scandals, and environmental disasters, among others, is changing the way in which stakeholders value the integration and management of issues related to sustainability, from a long-term value-added perspective on the investment itself (KPMG 2011).

Currently, a growing number of business organizations are including social and environmental factors in their strategic management policies. Porter and Kramer (2006) concluded that, if the different perspectives of stakeholders are not considered, there will be negative consequences for business competitiveness in the medium and long term. Financial markets have gradually incorporated new investment alternatives according to this new management model.

There is growing evidence that investors are willing to incorporate, for example, environmental, social, and governance issues into their investment decisions (Lombardo and D'Orio 2012). These investors seek to maximize the financial return on their investments without, however, questioning the sustainable development goals (Louche 2004; Statman and Glushkov 2008; Eurosif 2008). The awareness of sustainability goals has given rise to the emergence of sustainable stock indices, which are increasingly attracting investors' attention and interest (Louche 2004; Cortez et al. 2009).

So-called socially responsible investment (SRI), also known as ethical or sustainable investment (Renneboog et al. 2008), combines financial goals with non-financial goals, including environmental (environmental policy, external systems/internal management, climate change indicators, emissions, solid waste, water, etc.), social (labour and human rights, among others), and governance goals (good governance principles, existence of codes of ethics, etc.).

Understanding the linkages between international stock market indices has been a topic of study for financial researchers. Firstly, these linkages have implications for portfolio managers with respect to their investment decisions. The asset valuation theory suggests that international diversification reduces idiosyncratic risk. The intensification of co-movements among international stock markets negatively affects international diversification opportunities. Secondly, the interdependencies between markets carry significant consequences, both for policy makers and for regulators, particularly in terms of stabilizing financial markets. The risk of financial contagion has been fuelled by an increasingly globalized world. To minimize the contagion effects, policy makers and regulators should evaluate the interdependencies between markets to implement mechanisms for monitoring the international capital flows. Thirdly, understanding the volatility transmission between markets is essential for investors, since it significantly affects asset prices and the calculation of their respective risk premiums (Drakos et al. 2010; Ehrmann et al. 2011). 
With regard to the sustainable investment perspective, a crucial factor in the identification of potential benefits associated with international diversification is the degree of linkage and integration across sustainable thematic indices. According to the international portfolio diversification theory, low (high) linkage intensity among stock markets implies higher (lower) benefits of international diversification. However, there is no concrete knowledge about the linkages between socially responsible indices. A majority of the academic works developed with responsible indices have mainly studied the issue of the performance of these indices compared with that of conventional indices (Bauer et al. 2007; Edmans 2007; Leite and Cortez 2015). Most research has found that SRI funds do not perform differently from conventional funds (Statman 2006; Utz et al. 2014). Nofsinger and Varma (2013) tested the performance of US SRI funds against conventional funds, concluding that SRI funds outperform during periods of market crisis but at the cost of underperformance during non-crisis periods. In all these cases, the investigation focus was directed to the performance of SRI investment against conventional investment. However, little attention has been devoted to the subject of linkages between socially responsible indices and even less to linkages between environmentally sustainable investment indices.

This research intends to expand the existing financial literature, both in empirical and in methodological terms, to the analysis of the short-term and long-term linkages between sustainable global indices. The overwhelming majority of the existing works has tended to focus successively on the use of traditional indices, dominated by large caps and with a purely financial perspective, disregarding the environmental issues. There are no known studies that have focused on environmental indices. Consequently, our work fills an empirical research gap, studying the short-term and long-term linkages between five global thematic indices (alternative energy, clean technology, green building, sustainable water, and pollution prevention), concerning five segments of environmentally sustainable investment and analysing in particular the intensity, speed, and maturity of interactions. On the other hand, with this work we try to increase the knowledge about the behaviour of environmental indices and to determine whether the behaviour of environmental indices is guided by common market factors or by specific market factors, seeking to identify opportunities for investment diversification and adopting as the study perspective the operation of those market sectors.

Regardless of the methodology used, this work analyses the linkages between environmental indices, adopting a similar methodology to that applied and tested by several authors for conventional indices, considering both returns and volatility, estimated from an asymmetric multivariate model with conditional heteroskedasticity, to identify any differences in volatility reactions to positive and negative shocks.

This study is structured as follows: part 2 presents the literature review; part 3 discusses the methodology chosen; part 4 provides information about the data and empirical results; and part 5 briefly presents the main conclusions.

\section{LITERATURE REVIEW}

Several studies have tried to identify the main driving forces and barriers to SRI integration into the mainstream market. According to the literature, the main driving forces can be classified into three pressure groups: market, group, and institutional pressures. 
Market pressures are external forces promoting SRI integration, conducted by investors, analysts, and some companies that have adopted a reactive position toward SRI management (Slager 2012; Sievänen et al. 2013). Group pressures refer to initiatives undertaken by the members of the financial market to integrate SRI information into their investment decisions (Bassen and Kovacs 2008; Jemel-Fornetty et al. 2011). Finally, institutional pressures are forces exerted by non-members of the financial market, which are "light forces" or "strong forces" depending on whether they are voluntary or compulsory, like regulation (Knopf et al. 2010; Jemel-Fornetty et al. 2011).

Several studies have pointed out that the financial market knows about the potential advantages of SRI integration but that there are still too many barriers to exploit their full potential. The main barriers to this integration can be classified into three groups of difficulties: technical, internal, and external difficulties.

Technical difficulties refer to the complexity and difficulty involved in managing and measuring SRI issues, especially due to the lack of good public information (Igalens and Gond 2005), while internal difficulties are related to conditions that are particular to an investment institution and the interactions that arise between the individuals within an institution. In turn external difficulties are influenced by the conventions that prevail at the market level and the interactions between individuals in that setting, such as the unrealistic belief in the financial markets, supposing a negative relationship between social and financial performance (Guyatt 2006; Juravle and Lewis 2008; Perrini et al. 2012; Hoehler and Hespenheide 2013).

The subject of short-term and long-term linkages between international stock markets has received considerable academic attention in finance research, due largely to the seminal work of Grubel (1968). However, a large number of studies have investigated only the conventional indices, dominated by large caps and purely financial criteria, studies on environmental indices being lacking.

The results obtained in the first academic works were not always coincident. Ripley (1973) concluded that there was a degree of interdependence between open markets and investment and foreign capital flows. Conversely, Agmon (1972) and Branch (1974) did not find evidence of interdependence among international stock markets. Bertoneche (1979) identified a high degree of segmentation in several major stock markets. Similarly, Roll (1988) concluded that there was a low level of linkages between international stock markets.

Several studies have highlighted the role of the stock market crash of October 1987 as a factor that contributed to the approximation between stock markets (Eun and Shim 1989; Arshanapalli et al. 1995; Lau and McInish 1996).

Eun and Shim (1989) concluded that there were statistically significant interdependencies between nine international stock markets after the emergence of the 1987 crash. Studying the sample period from 1986 to 1989, Lau and McInish (1996) reached a similar conclusion. Finally, Arshanapalli et al. (1995) highlighted the role of the crash in similar and near answers by international stock markets. The occurrence of interdependencies and simultaneous responses, with statistical significance, such as those reported in the studies mentioned above, allows a certain degree of market behaviour predictability, questioning some assumptions of the efficient market hypothesis, according to which asset price behaviour is described by a random walk, which implies non-predictability (Fama 1970).

Studying a sample period of 150 years, Goetzmann et al. (2005) concluded that the correlation between stock markets changed considerably over this period, being particularly 
pronounced in periods of financial and economic integration. Similarly, Bekaert et al. (2007) highlighted the importance of markets' integration in the global context, the liberalization of capital markets, and the opening of stock markets and banking systems, reported as facilitating factors to deepen the linkages between international stock markets. Other recent studies have demonstrated the progressive strengthening of the linkages between stock markets and the role played by the US market in explaining the movements in other markets. Empirical examples are the research works of Peiro et al. (1998) and Ozdemir and Cakan (2007). Similarly, Park (2010) found evidence of strong co-movement between Asian markets. Among these the countries with the most developed financial systems (Japan, Singapore, and Hong Kong) exhibited strong linkages with the remaining Asian countries considered in the study. Recent studies have highlighted the role played by the global financial crisis in the strong convergence between stock markets. Using Granger causality tests and impulse response functions, Tudor (2011) concluded that the linkages between some Central and Eastern European stock markets and the US market were strengthened by the crisis. In turn Mandigma (2014) reached a similar conclusion by analysing the dynamic linkages between some Southeast Asian markets and the US stock market.

In addition to the academic works referenced above, the methodological base of which was mostly vector autoregression (VAR) and the Granger causality concept, other researchers have resorted to multivariate GARCH models to analyse the short-term linkages and the volatility transmission. According to several studies, the multivariate framework allows the volatility asymmetric effect and proves to be an important element to an appropriate specification of the conditional variance-covariance matrix in terms of asset allocation (Goeij and Marquering 2004) and asset price modelling (Bekaert and $\mathrm{Wu} 2000$ ) as well as for studying linkages between stock markets (Soriano and Climent 2006; Li and Majerowska 2008) and analysing hedging operations (Aragó and Salvador 2011).

The long-term relationships between international stock markets have also received much attention from finance researchers around the world. The majority of these works applied the Johansen cointegration approach. Cointegration entails several implications, especially for asset valuation. Firstly, the existence of cointegration between several stock markets implies that these markets share a common stochastic trend. Consequently, the potential benefits of long-term diversification will be reduced. Secondly, as stated by Granger (1986), the existence of cointegration can lead to the rejection of the efficient market hypothesis, implying a certain level of predictability.

Empirically, the literature devoted to the study of long-term linkages has produced mixed results, just like the academic work about short-term linkages. Using the Johansen cointegration approach, several studies have identified the existence of a common stochastic trend among international stock markets (Samitas and Kenourgios 2011; Tripathi and Sethi 2012). Alongside these academic works, Babecky et al. (2012) identified several cointegrating vectors between the G8 countries for the sample period between September 1995 and November 2010. An and Brown (2010) applied the same methodological approach to find a significant relationship between the US and the Chinese stock market. In their study Caporale et al. (2009) analysed the stock markets of Germany, France, the Netherlands, Ireland, and the United Kingdom for the sample period between 1973 and 2008 , but they did not find any evidence of cointegration. 
Also using the cointegration Johansen approach, other studies have concluded to the contrary, failing to identify a long-term relationship between stock markets (Li 2006; Olusi and Abdul-Majid 2008; Karim et al. 2010) or identifying very faint signs (Ahlgren and Antell 2002). According to Bley (2009), the occurrence of mixed results is strongly influenced by time and country factors.

\section{METHODOLOGY}

\subsection{Johansen cointegration test}

To study the long-term linkages between the global thematic indices, I applied the cointegration concept using the approach developed by Johansen (1988), which is especially useful in the multivariable case.

After test series integration, using the augmented Dickey-Fuller test, the Johansen cointegration approach, based on the vector error correction model (VECM), was applied according to the following form:

$$
\Delta Y_{t}=\Pi Y_{t-1}+\sum_{i=1}^{n-1} \Gamma_{i} \Delta Y_{t-i}+\mu+u_{t}
$$

The Johansen cointegration approach uses two likelihood ratio test statistics to test for the rank of the $\Pi$ matrix, namely the trace $\left(\lambda_{\text {trace }}\right)$ and the maximum eigenvalue statistics $\left(\lambda_{\max }\right)$ These statistics are expressed as follows:

$$
\lambda_{\text {trace }}=-T \sum_{i=r+1}^{k} \log \left(1-\lambda_{i}\right)
$$

The trace test tests the null hypothesis that the number of cointegrating vectors is $r$ against the alternative hypothesis that it is more than $r$.

In turn the maximum eigenvalue test is given by:

$$
\lambda_{\max }=-T \log \left(1-\lambda_{r+1}\right)
$$

The maximum eigenvalue statistic, on the other hand, has the null hypothesis that the number of cointegrating vectors is $r$ against an alternative of $r+1$.

\subsection{Multivariate GARCH-VECH model}

To investigate the volatility spillovers between the thematic indices, I estimated the multivariate GARCH model with diagonal VECH representation (Bollerslev et al. 1988) and considered the full rank matrix method, following the proposal of Ding and Engle (2001), guaranteeing a positive, semi-definite conditional variance-covariance matrix. Additionally, the asymmetric effect was incorporated into the model using the methodology proposed by Glosten et al. (1993) and applied by Karmakar (2010), which can be summarized by the following equation: 


$$
\operatorname{vech}\left(H_{t}\right)=C+\sum_{j=1}^{q} A_{j} \operatorname{vech}\left(\varepsilon_{t-1} \varepsilon_{t-1}^{\prime}\right)+\sum_{j=1}^{r} D_{j} \operatorname{vech}\left(\varphi_{t-1} \varphi_{t-1}^{\prime}\right)+\sum_{j=1}^{p} B_{j} \operatorname{vech}\left(H_{t-j}\right)
$$

\subsection{Causality tests}

To study the short-term linkages between the selected environmental indices and the direction of influence between them, I used the Granger causality concept, introduced by Granger (1969) and later popularized by Sims (1972), based on the assumption that $X_{t}$ causes $Y_{t}$ if the prediction of the $Y_{t}$ variable is improved with the lagged information of $X_{t}$, that is, if the prediction of $Y_{t}$ is more accurate when using the combined lagged information of $X_{t}$ and $Y_{t}$, than when considering only the information of $Y_{t}$. The Granger causality test was obtained from the VAR model estimates to determine whether the lags of the excluded variable affect the endogenous variable. This test is called the VAR Granger causality/block exogeneity Wald test, assuming the null hypothesis in which, in the Granger sense, the lagged endogenous variables do not cause the dependent variable.

\subsection{Impulse response functions}

To analyse the short-term linkages, impulse response functions should also be applied. Considering all the variables entered into the system, this approach provides a dynamic analysis, generated from the VAR model, allowing the analysis of the causal relationships even when they were not previously detected by the Granger causality test (Lutkepohl 1999).

The impulse response functions show how a particular variable responds to shocks from other variables in the system. In other words, an innovation in a given variable triggers a chain reaction over time in the remaining variables. The impulse response functions allow us to assess these chain reactions.

According to Aziakpono (2006) and Lutkepohl and Saikkonen (1997), if the process is white noise, then the estimated VAR can be converted into a moving average representation, the coefficients of which are forecast error impulse responses. The moving average is given by:

$$
Y_{t}=C+\sum_{s=0}^{k} B_{s} \varepsilon_{t-s}
$$

where $Y_{t}$ denotes a linear combination of current and past one-step-ahead forecast error innovations and the coefficient $\beta_{s}$ expresses the response of one stock market return to a one standard error shock of any of the markets under study $S$ periods ago.

In this study I selected generalized impulse response functions, which were introduced by Koop et al. (1996) and Pesaran and Shin (1998), and applied the Monte Carlo simulation procedure (repeated 1000 times). This approach differs from the traditional orthogonalized impulse response analysis, because it does not vary with the ordering of the variables in the VAR model. 


\section{DATA AND EMPIRICAL RESULTS}

\subsection{Data}

The data were collected from Morgan Stanley Capital International, which is considered to be a leading provider of market indices, benchmarks for investment funds, and portfolio risk and analytical tools, covering the period between January 2009 and October 2014, translated into 1490 daily observations and including 5 thematic indices, namely:

- Alternative Energy (AE) - this includes developed and emerging market large-, mid-, and small-cap companies that derive $50 \%$ or more of their revenues from products and services in alternative energy;

- Clean Technology (CT) - this includes developed and emerging market large-, mid-, and small-cap companies that derive $50 \%$ or more of their revenues from products and services in clean technology;

- Green Building (GB) - this includes developed and emerging market large-, mid-, and small-cap companies that derive $50 \%$ or more of their revenues from products and services in green building;

- Sustainable Water (SW) - this includes developed and emerging market large-, mid-, and small-cap companies that derive $50 \%$ or more of their revenues from products and services in sustainable water;

- Pollution Prevention (PP) - this includes developed and emerging market large-, mid, and small-cap companies that derive $50 \%$ or more of their revenues from products and services in pollution prevention.

The original closing prices were transformed into return series, $r_{t}$, through the application of the expression $\left(P_{t} P_{t-1}\right)$, where $P_{t}$ and $P_{t-1}$ are the closing values of a particular index on days $t$ and $t-1$, respectively.

\subsection{Empirical results}

The main descriptive statistics of the returns of the five environmental indices are given in Table 1.

The analysis of the descriptive statistics supports the conclusion that only the alternative energy index showed negative daily average returns. All the series showed signs of deviation from the normality assumption, given their skewness and kurtosis coefficients, which were different from zero and three, respectively. To test for the goodness of fit of the normal distribution to the empirical distribution of the five indices, the Jarque-Bera test was also applied, the statistics of which can be seen in Table 1. All the p-values (equal to zero) lead to the conclusion that all the series are statistically significant at the $1 \%$ level, clearly rejecting the normality assumption.

To ascertain the stationarity of the variables (levels and returns), the traditional augmented Dickey-Fuller (ADF) test was carried out. The null hypothesis $\left(H_{0}\right)$ requires the series to have a unit root or to be integrated of order 1 , I (1), given the alternative hypothesis $\left(H_{0}\right)$ that the series does not have a unit root or is I (0). The stationarity test results are shown in Table 1. All the return series showed strong evidence of stationary, I (0), at the 
significance level of $1 \%$, contrary to the level series, which proved to be integrated and therefore non-stationary.

Table 1

Descriptive Statistics

\begin{tabular}{|l|c|c|c|c|c|}
\hline & $\mathrm{AE}$ & $\mathrm{CT}$ & $\mathrm{GB}$ & $\mathrm{PP}$ & $\mathrm{SW}$ \\
\hline Mean & -0.00032 & 0.00049 & 0.00058 & 0.00079 & 0.00036 \\
\hline Median & 0.00007 & 0.00062 & 0.00097 & 0.00094 & 0.00061 \\
\hline Maximum & 0.08081 & 0.06000 & 0.08621 & 0.06981 & 0.06142 \\
\hline Minimum & -0.07432 & -0.06284 & -0.08064 & -0.08116 & -0.07328 \\
\hline Std. Dev. & 0.01723 & 0.01322 & 0.01480 & 0.01437 & 0.01239 \\
\hline Skewness & -0.12483 & -0.12074 & -0.20457 & -0.15447 & -0.18305 \\
\hline Kurtosis & 4.99694 & 5.59028 & 8.67407 & 5.71476 & 5.76003 \\
\hline Jarque-Bera (Prob.) & $(0.00000)$ & $(0.00000)$ & $(0.00000)$ & $(0.00000)$ & $(0.00000)$ \\
\hline ADF (Level) & $(0.73410)$ & $(0.31180)$ & $(0.52830)$ & $(0.72200)$ & $(0.62360)$ \\
\hline ADF (Return) & $(0.00000)$ & $(0.00000)$ & $(0.00000)$ & $(0.00000)$ & $(0.00000)$ \\
\hline
\end{tabular}

Note: Values between parentheses show probability values.

Source: Own elaboration.

To detect possible long-term relationships between the environmental indices, Johansen cointegration tests were estimated for every pair of indices and for all the five indices. The necessary condition for implementing cointegration tests is that the series have the same integration order. Taking into account the ADF results (Table 1), all the level series are I(1), satisfying the prerequisite of the cointegration tests.

The Johansen approach requires the prior estimation of a vector autoregressive model. A key element in specifying the vector model is the lag order. The optimal specification was obtained from the Akaike and Schwarz information criteria. The VAR lag order selection criteria indicated that the optimal lag is one.

After the VAR model estimation, the Johansen cointegration test was conducted, the statistics of which are summarized in Table 2, namely in the two columns on the right. The first column shows the trace test statistics, while the second column shows the maximum eigenvalue statistics. In both cases, the statistics' test value and probability of rejecting the null hypothesis, that there is no cointegrating vector, are shown.

Table 2

Bivariate Johansen's cointegration test results

\begin{tabular}{|c|c|c|}
\hline & $\begin{array}{c}\text { Trace Test } \\
\left(\lambda_{\text {trace }}\right)\end{array}$ & $\begin{array}{c}\text { Maximum Eingenvalue Test } \\
\left(\lambda_{\max }\right)\end{array}$ \\
\hline \multirow{2}{*}{ All } & 51.2954 & 31.5958 \\
& $(0.5807)$ & $(0.0914)$ \\
\hline
\end{tabular}




\begin{tabular}{|c|c|c|}
\hline \multirow{2}{*}{$\mathrm{AE} / \mathrm{CT}$} & $\begin{array}{c}8.2681 \\
(0.4372)\end{array}$ & $\begin{array}{c}6.6736 \\
(0.5284)\end{array}$ \\
\hline \multirow{2}{*}{$\mathrm{AE} / \mathrm{GB}$} & 7.2454 & 5.8449 \\
& $(0.5493)$ & $(0.6332)$ \\
\hline \multirow{2}{*}{$\mathrm{AE} / \mathrm{PP}$} & 4.9130 & 3.6503 \\
& $(0.8180)$ & $(0.8943)$ \\
\hline \multirow{2}{*}{$\mathrm{AE} / \mathrm{SW}$} & 5.1513 & 3.9631 \\
& $(0.7926)$ & $(0.8632)$ \\
\hline \multirow{2}{*}{$\mathrm{CT} / \mathrm{GB}$} & 7.0870 & 5.4962 \\
& $(0.5675)$ & $(0.6783)$ \\
\hline \multirow{2}{*}{$\mathrm{CT} / \mathrm{PP}$} & 6.2049 & 5.6490 \\
& $(0.6713)$ & $(0.6586)$ \\
\hline \multirow{2}{*}{$\mathrm{CT} / \mathrm{SW}$} & 8.3674 & 7.0322 \\
& $(0.4270)$ & $(0.4853)$ \\
\hline \multirow{2}{*}{$\mathrm{GB} / \mathrm{PP}$} & 7.6698 & 6.2084 \\
& $(0.5014)$ & $(0.5866)$ \\
\hline \multirow{2}{*}{$\mathrm{GB} / \mathrm{SW}$} & 10.6053 & 8.3324 \\
& $(0.2370)$ & $(0.3459)$ \\
\hline \multirow{2}{*}{$\mathrm{PP} / \mathrm{SW}$} & 7.1437 & $(0.6281)$ \\
& $(0.5610)$ & \\
\hline
\end{tabular}

Notes: This table shows Johansen cointegration test results between Alternative Energy (AE), Clean Technology (CT), Green Building (GB), Sustainable Water (SW) and Pollution Prevention (PP) thematic indices, considering all indices and the bivariate case. Values between parentheses show probability values.

Source: Own elaboration.

The null hypothesis of non-cointegration between all the indices, as well as the ten bivariate cases, was not rejected by the trace test and the maximum eigenvalue value, at the significance level of 5\%. These results are not in accordance with some other previous academic researchers, namely An and Brown (2010), Babecky et al. (2012), Caporale et al. (2009), Samitas and Kenourgios (2011), and Tripathi and Sethi (2012), in all cases considering conventional indexes.

All the cases revealed the absence of equilibrium relationships in the long run, so the environmental indices were not guided by common factors that limit their independent variation, allowing a certain degree of predictability. Rather, the non-equilibrium long-term relationships contribute to increasing the investment possibilities in the light of a possible international diversification strategy.

Taking into account the suggestions of Fama (1970) and Granger (1986), the non-equilibrium long-term relationship implies the acceptance of the efficient market hypothesis, which translates into an inability to predict long-term market behaviour.

To model own volatility effects and cross-volatility effects, the multivariate GARCH model, in the diagonal VECH form and the full rank matrix specification, was estimated. The estimated results for the variance-covariance parameters are presented in Table 3.

All the parameters showed high statistical significance, reflecting the obvious closeness between the environmental thematic indices. The parameters of the $\mathrm{C}$ matrix proved to be statistically significant at the significance level of $1 \%$, leading to the conclusion that 
volatility maintained a minimum level. The parameters of matrix A, indicating the ARCH effect, also proved to be significant at the same significance level, so own and cross past volatility have an impact on present volatility. The volatility showed high persistence in the variance and covariance structure, given the statistical significance and the high values of the B matrix coefficients. Finally, the clear statistical significance of the D matrix coefficients (significance level of 1\%) reveals evidence of asymmetric shocks in the conditional variance. Thus, negative own or cross shocks can generate sharper volatility than positive shocks of an equal size.

The results presented in Table 3 emphasize the heavy exposure of the five thematic indices relative to the volatility transmission process. With regard to volatility, the closeness between all the environmental indices was not different from that of conventional indices, considered by other research papers, in particular those of Li and Majerowska (2008) and Soriano and Climent (2006), among others. This proximity is a condition that is usually associated with the financial globalization process, which provides highly favourable conditions for interaction between international markets and even the occurrence of financial contagion phenomena, making a possible diversification investment strategy on a global scale difficult.

To analyse the thematic indices' behaviour, the average conditional correlations were calculated, generated from the multivariate GARCH model estimates. The results are reported in Table 4. All the average conditional correlations recorded positive values and showed moderate or high intensities, allowing the formation of the first idea that global thematic indices have closer relationships in the short term.

To analyse whether there are causal relationships between the five indices, the VAR Granger causality/block exogeneity Wald test approach was used, the null hypothesis of which establishes the absence of a causal relationship. This approach assesses the significance of each joint lagged endogenous variable in each VAR equation through the $c^{2}$ statistical values and simultaneously the joint significance of all the lagged endogenous variables, using F statistics. For each of the estimated equations, the Wald test statistics are provided based on the joint significance of each of the other endogenous variables, according to the selected lags, considering both the Akaike and the Schwarz information criterion.

Table 3

Multivariate GARCH estimates

\begin{tabular}{|c|c|c|c|c|c|c|c|c|c|c|}
\hline & \multicolumn{9}{|c|}{ Cij } & \multicolumn{3}{c|}{ Aij } \\
\hline & AE & CT & GB & PP & SW & AE & CT & GB & PP & SW \\
\hline \multirow{2}{*}{ AE } & 0.000 & & & & & 0.021 & & & & \\
\cline { 2 - 12 } & $(0.000)$ & & & & & $(0.000)$ & & & & \\
\hline \multirow{2}{*}{ CT } & 0.000 & 0.000 & & & & 0.017 & 0.014 & & & \\
\cline { 2 - 12 } & $(0.000)$ & $(0.000)$ & & & & $(0.000)$ & $(0.000)$ & & & \\
\hline \multirow{2}{*}{ GB } & 0.000 & 0.000 & 0.000 & & & 0.015 & 0.012 & 0.010 & & \\
\cline { 2 - 12 } & $(0.000)$ & $(0.000)$ & $(0.000)$ & & & $(0.000)$ & $(0.000)$ & $(0.000)$ & & \\
\hline
\end{tabular}




\begin{tabular}{|c|c|c|c|c|c|c|c|c|c|c|}
\hline \multirow{2}{*}{ PP } & 0.000 & 0.000 & 0.000 & 0.000 & & 0.016 & 0.013 & 0.011 & 0.012 & \\
\hline & $(0.000)$ & $(0.000)$ & $(0.000)$ & $(0.000)$ & & $(0.000)$ & $(0.000)$ & $(0.000)$ & $(0.000)$ & \\
\hline \multirow{2}{*}{ SW } & 0.000 & 0.000 & 0.000 & 0.000 & 0.000 & 0.013 & 0.011 & 0.009 & 0.010 & 0.009 \\
\hline & $(0.000)$ & $(0.000)$ & $(0.000)$ & $(0.000)$ & $(0.000)$ & $(0.000)$ & $(0.000)$ & $(0.000)$ & $(0.000)$ & 0.001 \\
\hline & \multicolumn{5}{|c|}{ Dij } & \multicolumn{5}{|c|}{$\mathrm{Bij}$} \\
\hline & $\mathrm{AE}$ & CT & GB & PP & SW & $\mathrm{AE}$ & CT & GB & $\mathrm{PP}$ & SW \\
\hline \multirow{2}{*}{$\mathbf{A E}$} & 0.011 & & & & & 0.959 & & & & \\
\hline & $(0.003)$ & & & & & $(0.000)$ & & & & \\
\hline \multirow{2}{*}{ CT } & 0.013 & 0.015 & & & & 0.961 & 0.964 & & & \\
\hline & $(0.000)$ & $(0.000)$ & & & & $(0.000)$ & $(0.000)$ & & & \\
\hline \multirow{2}{*}{ GB } & 0.018 & 0.021 & 0.029 & & & 0.959 & 0.962 & 0.960 & & \\
\hline & $(0.000)$ & $(0.000)$ & $(0.000)$ & & & $(0.000)$ & $(0.000)$ & $(0.000)$ & & \\
\hline \multirow{2}{*}{$\mathbf{P P}$} & 0.016 & 0.019 & 0.026 & 0.024 & & 0.958 & 0.961 & 0.959 & 0.957 & \\
\hline & $(0.000)$ & $(0.000)$ & $(0.000)$ & $(0.000)$ & & $(0.000)$ & $(0.000)$ & $(0.000)$ & $(0.000)$ & \\
\hline \multirow{2}{*}{ SW } & 0.021 & 0.024 & 0.034 & 0.031 & 0.039 & 0.951 & 0.954 & 0.952 & 0.951 & 0.944 \\
\hline & $(0.000)$ & $(0.000)$ & $(0.000)$ & $(0.000)$ & $(0.000)$ & $(0.000)$ & $(0.000)$ & $(0.000)$ & $(0.000)$ & $(0.000)$ \\
\hline
\end{tabular}

Notes: This table shows the Multivariate GARCH Vech estimates produced for Alternative Energy (AE), Clean Technology (CT), Green Building (GB), Sustainable Water (SW) and Pollution Prevention (PP) thematic indices. Values between parentheses show probability values.

Source: Own elaboration.

Table 4

\section{Average of conditional correlations}

\begin{tabular}{|c|c|c|c|c|c|}
\hline & AE & CT & GB & PP & SW \\
\hline AE & 1 & & & & \\
\hline $\mathrm{CT}$ & 0.711 & 1 & & & \\
\hline GB & 0.664 & 0.820 & 1 & & \\
\hline PP & 0.654 & 0.802 & 0.781 & 1 & \\
\hline SW & 0.575 & 0.760 & 0.724 & 0.764 & 1 \\
\hline
\end{tabular}

Notes: This table shows the average of conditional correlations between Alternative Energy (AE), Clean Technology (CT), Green Building (GB), Sustainable Water (SW) and Pollution Prevention (PP) thematic indices, produced from the multivariate GARCH Vech. Values between parentheses show probability values.

Source: Own elaboration.

Table 5 summarizes the results of the Granger causality tests. These results revealed several unidirectional relationships with statistical significance, consistent with the results of other recent studies on conventional indices, particularly those by Goetzmann et al. 
(2005), Bekaert et al. (2007), Ozdemir and Cakan (2007), Tudor (2011) and Mandigma (2014), among others. This allows the formation of the idea that the return-generating mechanism associated with the environmental indices does not differ significantly from the generating mechanism of the conventional indices.

The alternative energy index proved to be the most endogenous, due to being Granger caused by three indices. The least endogenous index was the sustainable water sector, which was not individually Granger caused by any of the remaining indices, allowing the conclusion that its behaviour was characterized by a certain degree of autonomy. It is also important to highlight the fact that the AE, CT, and GB indices' movements are caused, in the Granger sense, by the joint lagged movements of the five indices. In terms of exogeneity, the sustainable water index stood out in comparison with the other indices, containing information about the behaviour of the remaining indices. Thus, this index may be considered a market driver, helping to explain the movements of the other indices. On the other hand, the $\mathrm{AE}$ and GB indices did not help to explain the movements in the other indices.

Table 5

Granger Causality Tests/Block Exogeneity Wald Tests

\begin{tabular}{|c|c|c|c|c|c|c|}
\hline & & \multicolumn{4}{|c|}{ Dependent Variables } & \multirow[b]{2}{*}{ SW } \\
\hline & & $\mathbf{A E}$ & CT & GB & PP & \\
\hline \multirow{12}{*}{ 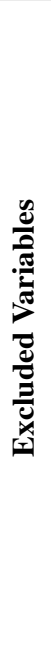 } & \multirow{2}{*}{$\mathbf{A E}$} & & 0.079 & 0.402 & 0.485 & 0.101 \\
\hline & & & $(0.778)$ & $(0.526)$ & $(0.486)$ & $(0.751)$ \\
\hline & \multirow{2}{*}{ CT } & 5.746 & & 0.916 & 0.436 & 0.075 \\
\hline & & $(0.017)$ & & $(0.339)$ & $(0.509)$ & $(0.784)$ \\
\hline & \multirow{2}{*}{ GB } & 0.711 & 0.789 & & 0.004 & 1.435 \\
\hline & & $(0.399)$ & $(0.374)$ & & $(0.948)$ & $(0.231)$ \\
\hline & \multirow{2}{*}{$\mathbf{P P}$} & 4.664 & 1.624 & 3.154 & & 0.024 \\
\hline & & $(0.031)$ & $(0.203)$ & $(0.076)$ & & $(0.876)$ \\
\hline & \multirow{2}{*}{ SW } & 8.787 & 17.174 & 15.715 & 4.150 & \\
\hline & & $(0.003)$ & $(0.000)$ & $(0.000)$ & $(0.042)$ & \\
\hline & \multirow{2}{*}{ All } & 20.103 & 25.072 & 28.899 & 5.011 & 1.491 \\
\hline & & $(0.001)$ & $(0.000)$ & $(0.000)$ & $(0.286)$ & $(0.828)$ \\
\hline
\end{tabular}

Notes: This table shows Granger causality test results between Alternative Energy (AE), Clean Technology (CT), Green Building (GB), Sustainable Water (SW) and Pollution Prevention (PP) thematic indices, produced from vector autoregressive estimates. Values between parentheses show probability values.

Source: Own elaboration.

The statistical significance of some causal relationships violates the random walk model, taking into account the efficient market hypothesis proposed by Fama (1970). In some 
cases movements in a particular index are preceded by lagged movements in other indices, which results in a certain degree of predictability, creating the conditions for arbitrage operations.

The Granger causality test helps to provide an understanding of the existence of causal relationships between all the indices but does not help to detect a positive or negative effect or even to determine whether some relationships are stronger than others. To this end I used the generalized impulse response functions, corresponding to one standard error shock to any of the stock markets under study, to obtain additional evidence about the short-term movements and the transmission mechanisms. The results regarding the impulse response functions are summarized in Table 6 . All the responses, without exception, showed a positive sign, as was expected, following the direction of the index variation where the shock originated.

Table 6

Impulse Response Functions: Summary of Results

\begin{tabular}{|c|c|c|c|c|c|}
\hline & $\mathbf{A E}$ & $\mathbf{C T}$ & $\mathbf{G B}$ & $\mathbf{P P}$ & $\mathbf{S W}$ \\
\hline \multirow{4}{*}{$\mathbf{A E}$} & & 2 & 2 & 2 & 2 \\
& & 1,2 & 1,2 & 1,2 & 1,2 \\
\cline { 2 - 6 } & &,++ &,++ &,++ &,++ \\
\hline \multirow{4}{*}{$\mathbf{C T}$} & 2 & & 2 & 2 & 2 \\
& 1,2 & & 1,2 & 1,2 & 1,2 \\
\cline { 2 - 6 } &,++ & &,++ &,++ &,++ \\
\hline \multirow{4}{*}{ GB } & 2 & 2 & & 2 & 2 \\
& 1,2 & 1,2 & & 1,2 & 1,2 \\
&,++ &,++ & &,++ &,++ \\
\hline \multirow{3}{*}{ PP } & 2 & 2 & 2 & & 1,2 \\
& 1,2 & 1,2 & 1,2 & &,++ \\
\hline \multirow{3}{*}{ SW } &,++ &,++ &,++ & 1 & \\
\cline { 2 - 6 } & 1 & 1 & 1 & 1 & \\
\hline
\end{tabular}

Notes: market responses in rows, impulses from markets in columns; each cell has three rows: the first row indicates the number of days during which each market response was statistically significant, according to the criterion of one standard deviation, the second row indicates the number of order of these days and the third row indicates the signal of the impulse response.

Source: Own elaboration.

The response functions to impulses generated from the VAR model highlight that the five indices showed statistically significant reactions as a result of shocks in the remaining indices. A significant amount of these impulses (80\%) produced statistically significant effects for two days and then faded. The only exception was the sustainable water index (AS), the effects of which were less persistent, fading at the end of the day, reinforcing the idea that this thematic index, besides being more autonomous than the remaining indices, experiences less durable reactions. 
When comparing the results of the impulse response functions obtained in this study with those of other recent academic work, including Tudor (2011), it is possible to conclude that the reactions were less persistent, suggesting that the environmental indices process the market information more quickly than the conventional indices.

\section{SUMMARY AND CONCLUSIONS}

The study of the linkages and interdependencies between stock markets has been a very popular topic of study in finance. The absence of linkages between markets represents an advantage for portfolio investment diversification in a global context. The vast majority of academic works devoted to this theme have focused on financial issues and disregarded sustainability issues.

In this study five global thematic indices, representing the environmentally sustainable investment sector, were considered with the aim of analysing the short-term and long-term dynamics between them.

The short-term dynamic study started with the estimation of the multivariate GARCH asymmetric model to analyse the volatility transmission process. The results clearly showed a volatility contagion effect between all the environmental indices but also identified the occurrence of a strong asymmetric volatility effect, with negative shocks producing faster and stronger reactions than positive shocks of an equal size; therefore, the behaviour of the environmental indices does not seem to be differentiated from the behaviour of the conventional indexes.

The application of Granger causality tests and the estimation of the impulse response functions, both from the vector autoregression, expanded the study of short-term dynamics. The results of Granger causality tests showed the existence of some unidirectional linkages between the environmental indices. The sustainable water index stood out from its peers as the least endogenous but also the most exogenous, which reflects simultaneously a certain autonomous behaviour and a high capacity to explain movements in the remaining indices, questioning the random walk hypothesis. In turn the impulse response functions showed that the responses were positive and slightly persistent, particularly the sustainable water segment, reflecting the high speed with which markets accommodate information.

To investigate possible long-term relationships, the Johansen cointegration approach was applied to all the five indices and to each bivariate case. The results obtained showed the absence of long-term equilibrium relationships, so the environmental indices were not guided by common factors, limiting their independent movements and generating a certain degree of predictability, but rather showed autonomous behaviour, not questioning the assumptions of the efficient market hypothesis and paving the way to a possible strategy to diversify investment.

The results obtained in this study show that, from the short-term investment perspective, the behaviour of the environmental indices, considering both volatilities and returns, does not differ significantly from that of the traditional indices, following a very similar operating logic. However, adopting a long-term perspective, the environmental indices seem to be a good choice relative to international investment allocation and to investment diversification as an alternative to the traditional indices. 
The results also demonstrate the need for academics and investors to deepen the study of the behaviour of environmental indices not only by incorporating environmental, governance, and sustainability dimensions but also by providing a new perspective on investment allocation.

The major limitation of this work is related to the absence of previous studies on the interdependencies between environmental indices, which made it impossible to compare the results. Alternatively, the researcher chose to compare the results with those generated from conventional indices. Moreover, the study involved an analysis of a sample of approximately six years. Therefore, the generation of new results, increasing the length of the sample, would enable more accurate conclusions to be obtained.

In upcoming research I will focus on the theme of stock market linkages, again emphasizing the use of environmental segments, to study alternative investment allocation based on optimization models.

\section{REFERENCES}

Agmon, T., 1972. The relations among equity markets: a study of share price comovements in the United States, United Kingdom, Germany and Japan. Journal of Finance, 27, 839-855.

Ahlgren, N. and Antell, J., 2002. Testing for cointegration between international stock prices. Applied Financial Economics, 12, 851-861.

An, L. and Brown, D., 2010. Equity Market Integration between the US and BRIC Countries: Evidence from Unit Root and Cointegration Test. Research Journal of International Studies, 16.

Aragó, V. and Salvador, E., 2011. Sudden changes in variance and time varying hedge ratios. European Journal of Operational Research, 215, 393-403.

Arshanapalli, B., Doukas, J. and Lang, L., 1995. Pre and post-October 1987 stock market linkages between U.S. and Asian markets. Pacific-basin Finance Journal, 3, 57-73.

Aziakpono, M., 2006. Financial Integration amongst the SACU countries: evidence from Interest Rate Pass-Through Analysis. Studies in Economics and Econometrics, 30 (2).

Babecký, J., Komárek, L. and Komárková, Z., 2012. Integration of Chinese and Russian Stock Markets with World Markets: National and Sectoral Perspectives, BOFIT- Institute for Economies in Transition Bank of Finland Discussion Papers, 4.

Bassen, A., and Kovacs, M., 2008. Environmental, Social and Governance Key Performance Indicators from a Capital Market Perspective. ZeitschriftfürWirtschafts- und Unternehmensethik, 9(2), 182-192.

Bauer, R., Derwall, J. and Otten, R., 2007. The ethical mutual fund performance debate: new evidence from Canada. Journal of Business Ethics, 70, 111-24.

Bekaert, G., Harvey, C, Lundblad, C. and Siegel, S., 2007. Global growth opportunities and market integration. Journal of Finance, 62 (3), 1081-1137.

Bekaert, G. and Wu, G., 2000. Asymmetric volatility and risk in equity markets. Review of Financial Studies, 13 (1), 1-42.

Bertoneche, M., 1979. An empirical analysis of the interrelationships among equity markets under changing exchange rate systems. Journal of Banking and Finance, 3 (4), 397-405. 
Bley, J., 2009. European stock market integration: Fact or fiction?, International Financial Markets, Institutions and Money, 19, 759-776.

Bollerslev, T., Engle, R. and Wooldridge, J., 1988. A Capital asset pricing model with time-varying covariances. Journal of Political Economy, 96 (1), 116-131.

Branch, B., 1974. Common stock performance and inflation: an international comparison. Journal of Business, 47, 48-52.

Caporale, G.M., Erdogan, B. and Kuzin, V., 2009. Testing for Convergence in Stock Markets: A Non-Linear Factor Approach, Cesifo Workıng Paper No. 2845 Category 7: Monetary Policy and International Finance.

Cortez, M., Silva, F. and Areal, N., 2009. The performance of European socially responsible funds. Accessed November 2014, http://www.ifkcfs.de/fileadmin/ downloads/ events/ conferences/2008-Asset_Cortez_Silva_Areal.pdf

Dickey, D. and Fuller, W., 1979. Distribution of the estimators for time series regressions with a unit root. Journal of the American Statistical Association, 74, 427-31.

Ding, Z. and Engle, R., 2001. Large scale conditional covariance matrix modeling, estimation and testing. Academia Economic Papers, 29, 157-184.

Drakos, A., Kouretas, G. and Zarangas, L., 2010. Forecasting financial volatility of the Athens stock exchange daily returns: an application of the asymmetric normal mixture GARCH model. International Journal of Finance and Economics, 15, 331-350.

Edmans, A., 2007. Does the stock market fully value intangibles? Employee satisfaction and equity prices. Working paper, MIT, Cambridge, MA.

Ehrmann, M., Fratzscher, M. and Rigobon, R., 2011. Stock, Bonds, Money Markets and Exchange Rates: Measuring International Financial Transmission. Journal of Applied Econometrics, 26, 948-974.

Eun, C. and Shim, S., 1989. International transmission of stock market movements. Journal of Financial and Quantitative Analysis, 24, 241-256.

European Sustainable Investment Forum - Eurosif, 2008. "High Net Worth Individuals (HNWI) and Sustainable Investment 2008.” Accessed december 2014, http://www.eurosif. org/research/hnwi-a-sustainable investment/2008.

Fama, E., 1970. Efficient capital markets: A review of empirical work. Journal of Finance, 25, 383-417.

Freeman, R.E., 2008. Ending the so-called "Friedman-Freeman" debate, in: Agle, B.R., Donaldson, T., Freeman, R.E., Jensen, M.C., Mitchell, R. and Wood, D.J. (2008) Dialogue: Towards a superior Stakeholder Theory. Business Ethics Quarterly, 18, 153-190.

Friedman, M., 1970. The Social Responsibility of Business is to Increase Its Profits. New York Times, 13, 122-126.

Glosten, L., Jaganathan, R. and Runkle, D., 1993. On the relation between the expected value and the volatility of the nominal excess return on stocks. Journal of Finance, 48 (5), 1779-1801.

Goeij, P. and Marquering, W., 2004. Modeling the conditional covariance between stock and bond returns: a multivariate GARCH approach. Journal of Financial Econometrics, 2, 531-564.

Goetzmann, W., Li, L. and Rouwenhorst, K., 2005. Long-term global market correlations. Journal of Business, 78 (1), 1-38. 
Granger, C., 1969. Investigating causal relationships by econometric models and cross-spectral methods. Econometrica, 37 (3), 424-438.

Granger, C.W., 1986. Developments in the study of cointegrated economic variables. $O x$ ford Bulletin of Economics and Statistics, 48, 213-228.

Grubel, H., 1968. Internationally diversified portfolios: welfare gains and capital flows. American Economic Review, 58, 1299-1314.

Guyatt, D., 2006. Identifying and Overcoming Behavioural Impediments to Long Term Responsible Investments-a Focus on United Kingdom Institutional Investors. $\mathrm{PhD}$ Thesis, University of Bath (United Kingdom).

Hoehler, D. and Hespenheide, E., 2013. Finding the Value in Environmental, Social and Governance Performance. Deloitte Review (Complimentary article reprint), 12(2), 99111.

Igalens, J. and Gond, J., 2005. Measuring Corporate Social Performance in France: A Critical and Empirical Analysis of ARESE Data. Journal of Business Ethics, 56(2), 131-148.

Jemel-Fornetty, H., Louche, C. and Bourghelle, D., 2011. Changing the Dominant Convention: The Role of Emerging Initiatives in Mainstreaming ESG, in William Sun, Céline Louche, Roland Pérez (ed.) Finance and Sustainability: Towards a New Paradigm? A Post-Crisis Agenda (Critical Studies on Corporate Responsibility, Governance and Sustainability, Volume 2) Emerald Group Publishing Limited, 85-117.

Johansen, S., 1988. Statistical analysis of cointegration vectors. Journal of Economic Dynamics and Control, 12, 231-454.

Juravle, C. and Lewis, A., 2008. Identifying impediments to SRI in Europe: a review of the practitioner and academic literature. Business Ethics: A European Review, 17(3), 285-310.

Karim, B. A., Kassim, N. A. and Arip, M. A., 2010. The subprime crisis and Islamic stock markets integration. International Journal of Islamic and Middle Eastern Finance and Management, 3 (4), 363-371.

Karmakar, M., 2010. Information transmission between small and large stocks in the national stock exchange in India: an empirical study. Quarterly Review of Economics and Finance, 50, 110-120.

Knopf, J., Kahlenborn, W., Hajduk, T., Weiss, D., Feil, M., Fiedler, R. and Klein, J., 2010. National Public Policies in the European Union. Luxembourg: Publications Office of the European Union.

KPMG, 2011. Sustainable Insight: articulating the value of sustainability to mainstream investors." Accessed October 2014, http://www.csreurope.org/data/files/ For_news/ Sustai nable_Insight_Jan_2011_2.p df.

Lau, S. and McInish, T., 1996. Comovements of international equity returns: a comparison of pre- and post-October 19, 1987, periods. Global Finance Journal, 4, 1-19.

Leite, P. and Cortez, M., 2015. Performance of European socially responsible funds during market crises: Evidence from France. International Review of Financial Analysis, 40, 132-141.

Li, H. and Majerowska, E., 2008. Testing stock market linkages for Poland and Hungary: a multivariate GARCH approach. Research in International Business and Finance, 22, 247-266. 
Li, X-M, 2006. A revisit of international stock market linkages: new evidence from rank tests for nonlinear cointegration. Scottish Journal of Political Economy, 53 (2), 174-197.

Lombardo, R. and G. D’Orio, 2012. Corporate and state social responsibility: a long term perspective. Modern Economy, 3, 91-99.

Louche, C., 2004. Ethical Investment Processes and mechanisms of institutionalisation in the Netherlands 1990-2002. PhD dissertation, Erasmus University Rotterdam.

Lutkepohl, H., (1999). Vector Autoregressions. Unpublished manuscript, Institut für Statistik und Ökonometrie, Humboldt-Universitat zu Berlin.

Lutkepohl, H. and Saikkonen, P. (1997). Impulse Response Analysis in Infinite Order Cointegrated Vector Autoregressive Processes. Journal of Econometrics, 81, 127-157.

Koop, G., Pesaran, M., and Potter, S. (1996). Impulse response analysis in non-linear multivariate models. Journal of Econometrics, 74, 119-147.

Mandigma, M., 2014. Stock market linkages among the ASEAN 5+3 countries and US: further evidence. Management and Administrative Sciences Review, 3, 53-68.

Nofsinger, J. and Abhishek, V., 2014. Socially Responsible Funds and Market Crises. Journal of Banking and Finance, 48, 180-193.

Olusi, O. and Abdul-Majid, H., 2008. Diversification prospects in Middle East and North Africa (MENA) equity markets: a synthesis and an update. Applied Financial Economics, 18, 1451-1463.

Ozdemir, Z. and Cakan, E., 2007. Non-linear dynamic linkages in the international stock markets. Physica A: Statistical Mechanics and its Applications, 377, 173-180.

Park, J. W., 2010. Comovement of Asian stock markets and the U.S. influence. Global Economy and Finance Journal, 3, 76-88.

Peiro, A., Quesada, J. and Ezequiel, U., 1998. Transmission of movements in stock markets. The European Journal of Finance, 4, 331-343.

Pesaran, H. and Shin, Y., 1998. Generalized impulse response analysis in linear multivariate models. Economics Letter, 58, 17-29.

Porter, M.E. and Kramer, M.R., 2006. Strategy and society: The link between competitive advantage and corporate social responsibility. Harvard Business Review, 84, 42-56.

Renneboog, L., Ter Horst, J. and Zhang, C., 2008. Socially responsible investments: Institutional aspects, performance, and investor behavior. Journal of Banking and Finance, 32, 1723-1742.

Ripley, D., 1973. Systematic elements in the linkage of national stock market indices. $R e$ view of Economics and Statistics, 55 (3), 356-361.

Roll, R., 1988. The international crash of October 1987. Financial Analysts Journal, 44, pp. 19-35.

Samitas, A., and Kenourgios, D., 2011. Equity market integration in emerging Balkan markets. Research in International Business and Finance, 25, 296-307.

Sievänen, R., Hannu, R. and Scholtens, B., 2013. The Drivers of Responsible Investment: The Case of European Pension Funds. Journal of Business Ethics, 117(1), 137-151.

Sims, C., 1972. Money, Income and causality. American Economic Review, 62, 540-552.

Slager, C., 2012. Calculative Routines and Dynamic Reactivity: How an SRI Index Shapes CSR Practices. Academy of Management Best Paper Proceedings.

Soriano, P. and Climent, F., 2006. Region vs industry effects and volatility transmission. Financial Analyst Journal, 62 (6), 52-64. 
Statman, M., 2006. Socially Responsible Indexes. The Journal of Portfolio Management, 32(3), 100-109.

Statman, M. and Glushkov, D., 2008. "The wages of social responsibility." Accessed December 2014, http://www.socialinvest.org/resources/research/documents/2008 Winni ngPrizeMoskowitz.pdf

Tripathi, V. and Sethi, S., 2012. Inter linkages of Indian stock market with advanced emerging markets. The Asian Economic Review, 54, 507-528.

Tudor, C., 2011. Changes in stock markets interdependencies as a result of the global financial crisis: Empirical investigation on the CEE region. Panoeconomicus, 4, 525-543.

Utz, S., Wimmer, M., Hirschberger, M. and Steuer, R., 2014. Tri-criterion inverse portfolio optimization with application to socially responsible mutual fund. European Journal of Operational Research, 234 (2), 491-498.

Wood, D.J., 2008. Corporate Responsibility and Stakeholder Theory: Callenging the Neoclassical Paradigm, in: Agle, B.R., Donaldson, T., Freeman, R.E., Jensen, M.C., Mitchell, R. and Wood, D.J., 2008. Dialogue: Towards a superior Stakeholder Theory. Business Ethics Quarterly, 18, 153-190. 
